\title{
The current status of nitrogen fertiliser use efficiency and future research directions for the Australian cotton industry
}

\author{
MACDONALD Ben C. T..$^{*}$ (D), LATIMER James O. ${ }^{1,2}$, SCHWENKE Graeme D. ${ }^{3}$, NACHIMUTHU Gunasekhar ${ }^{4}$ \\ and BAIRD Jonathan $C^{4}$
}

\begin{abstract}
Fifty years of sustained investment in research and development has left the Australian cotton industry well placed to manage nitrogen $(\mathrm{N})$ fertiliser. The average production in the Australian cotton industry today is greater than two tonnes of lint per hectare due to improved plant genetics and crop management. However, this average yield is well below the yield that would be expected from the amount of $\mathrm{N}$ fertiliser used. It is clear from the recent studies that across all growing regions, conversion of fertiliser $\mathrm{N}$ into lint is not uniformly occurring at application rates greater than $200-240 \mathrm{~kg} \cdot \mathrm{hm}^{-2}$ of $\mathrm{N}$. This indicates that factors other than $\mathrm{N}$ availability are limiting yield, and that the observed nitrogen fertiliser use efficiency (NFUE) values may be caused by subsoil constraints such as sodicity and compaction. There is a need to investigate the impact of subsoil constraints on yield and NFUE. Gains in NFUE will be made through improved N fertiliser application timing, better targeting the amount of fertiliser applied for the expected yield, and improved soil $\mathrm{N}$ management. There is also a need to improve the ability and confidence of growers to estimate the contribution of soil $\mathrm{N}$ mineralisation to the crop $\mathrm{N}$ budget. Many Australian studies including data that could theoretically be collated in a meta-analysis suggest relative NFUE values as a function of irrigation technique; however, with the extensive list of uncontrolled variables and few studies using non-furrow irrigation, this would be a poor substitute for a single field-based study directly measuring their efficacies. In irrigated cotton, a re-examination of optimal NFUE is due because of the availability of new varieties and the potential management and long-term soil resilience implications of the continued removal of mineralised soil N suggested by high NFUE values. NFUE critical limits still need to be derived for dryland systems.
\end{abstract}

Keywords: Nitrogen fertiliser, Nitrogen use efficiency, Dryland, Irrigated

\section{Introduction}

Nitrogen $(\mathrm{N})$ is the main nutrient by mass that limits plant growth if the soil supply is inadequate. The requirement for organic and synthetic amendments to increase yield and facilitate crop growth has long been recognised by farmers. Synthetic N fertiliser produced via the Haber-Bosch process was a key component of the green revolution that increased agricultural productivity and alleviated hunger for many across the globe. Synthetic $\mathrm{N}$ fertiliser also underpins fibre and oil productivity in dryland and irrigated cotton systems globally. Over the

\footnotetext{
* Correspondence: ben.macdonald@csiro.au

${ }^{1}$ CSIRO Agriculture and Food, Black Mountain, Canberra, ACT, Australia

Full list of author information is available at the end of the article
}

last 37 years, the average Australian cotton lint yield has increased by $57 \%$ to $2360 \mathrm{~kg} \cdot \mathrm{hm}^{-2}$ (Cotton Australia 2017) due to improved crop genetics, irrigation practice and farm management which includes increased $\mathrm{N}$ fertiliser use and improved pest controls.

There are concerns about $\mathrm{N}$ fertiliser use efficiency (NFUE) in the Australian cotton industry and the potential for off-site impacts (Roth 2010). Over application of fertilisers contributes to global warming due to the emission of nitrous oxide $\left(\mathrm{N}_{2} \mathrm{O}-\mathrm{N}\right)$ and nitrogen oxides $\left(\mathrm{NO}_{\mathrm{x}}-\mathrm{N}\right)$, and the volatilisation of ammonia $\left(\mathrm{NH}_{3}-\mathrm{N}\right)$, as well as pollution of surface and ground waters, due to run-off and leaching of dissolved organic $\mathrm{N}(\mathrm{DON}-\mathrm{N})$, urea $\left(\mathrm{CON}_{2} \mathrm{H}_{4}-\mathrm{N}\right)$, and nitrate $\left(\mathrm{NO}_{3}{ }^{-} \mathrm{N}\right)$

(c) The Author(s). 2018 Open Access This article is distributed under the terms of the Creative Commons Attribution 4.0 International License (http://creativecommons.org/licenses/by/4.0/), which permits unrestricted use, distribution, and reproduction in any medium, provided you give appropriate credit to the original author(s) and the source, provide a link to the Creative Commons license, and indicate if changes were made. The Creative Commons Public Domain Dedication waiver (http://creativecommons.org/publicdomain/zero/1.0/) applies to the data made available in this article, unless otherwise stated. 
(Vitousek et al. 2009). In cotton, over-application of fertiliser $\mathrm{N}$ can negatively affect yields by encouraging "rank growth" and fruit shedding, reducing lint production, hampering defoliation, encouraging insects and disease, and delaying plant maturity (Rochester 2001). Over-fertilisation also affects secondary income from cotton crops by reducing cotton seed oil content (Pettigrew and Dowd 2014).

The Australian cotton industry has been researching fertiliser $\mathrm{N}$ application and productivity over the last 50 years. This paper represents an assessment of the current status of NFUE in the Australian cotton sector, and will identify key areas for future research.

\section{Background and methods}

\section{The Australian cotton industry}

The Australian cotton industry is split between dryland and irrigated cotton production. The exact aerial extent of each is dependent on water availability - both irrigation water availability and available soil water at sowing - , and thus the planting areas vary on a year to year basis (Fig. 1). In 2017 the industry produced 900 million $\mathrm{kg}$ of lint from $4700 \mathrm{~km}^{2}$, of which $77 \%$ was irrigated. Cotton is grown from northern Queensland to southern New South Wales (NSW) in semi-arid through to tropical savanna climates in six different geographic regions (Central Queensland, Darling Downs, Macintyre-Balonne, Northern NSW, Macquarie and Southern NSW). The average lint yield across the whole industry in 2017 was $2.3 \mathrm{t} \cdot \mathrm{hm}^{-2}$, and the top $20 \%$ of growers produced 3.1 $\mathrm{t} \cdot \mathrm{hm}^{-2}$. The industry-wide average revenue was \$AU
$6565 \mathrm{hm}^{-2}$ of cotton produced, with operating costs of \$AU $4500 \mathrm{hm}^{-2}$, of which fertiliser costs were \$AU 591 $\mathrm{hm}^{-2}$, or 13\% of the operating costs (Boyce 2017).

\section{Calculation of national and regional scale nitrogen fertiliser use efficiency}

Annual Australian cotton planting area and yield data for irrigated and dryland cropping by region were sourced from the Cotton Yearbook for each year (Anon 2017). The applied fertiliser $\mathrm{N}$ as a national average within the industry was sourced from Sparks (2017); note that this fertiliser data were generated from grower surveys and were estimates of the $\mathrm{N}$ applied and not the actual amount. Regional fertiliser $\mathrm{N}$ data were sourced from Roth Rural (2014), and similarly to the national data, the informations were sourced from grower surveys.

NFUE is a simple measure for evaluating efficiency of the conversion of fertiliser $\mathrm{N}$ into cotton lint (Eq. 1).

$$
N F U E=\frac{\text { Lint produced }\left(\mathrm{kg} \cdot \mathrm{hm}^{-2}\right)}{N \text { fertiliser applied }\left(\mathrm{kg} \cdot \mathrm{hm}^{-2}\right)}
$$

Rochester (2014) found that the NFUE benchmark for growing cotton should be between 13 and 18 . While seasonal weather conditions will dictate the final yield in any specific year, continual NFUE values $<13$ indicate that other production constraints are limiting yield, and that changing rate, placement or timing will not improve $\mathrm{N}$ uptake. Essentially, under this scenario the grower is continually over-fertilising for the yield potential of the crop. NFUE values $>18$ indicate that soil organic matter

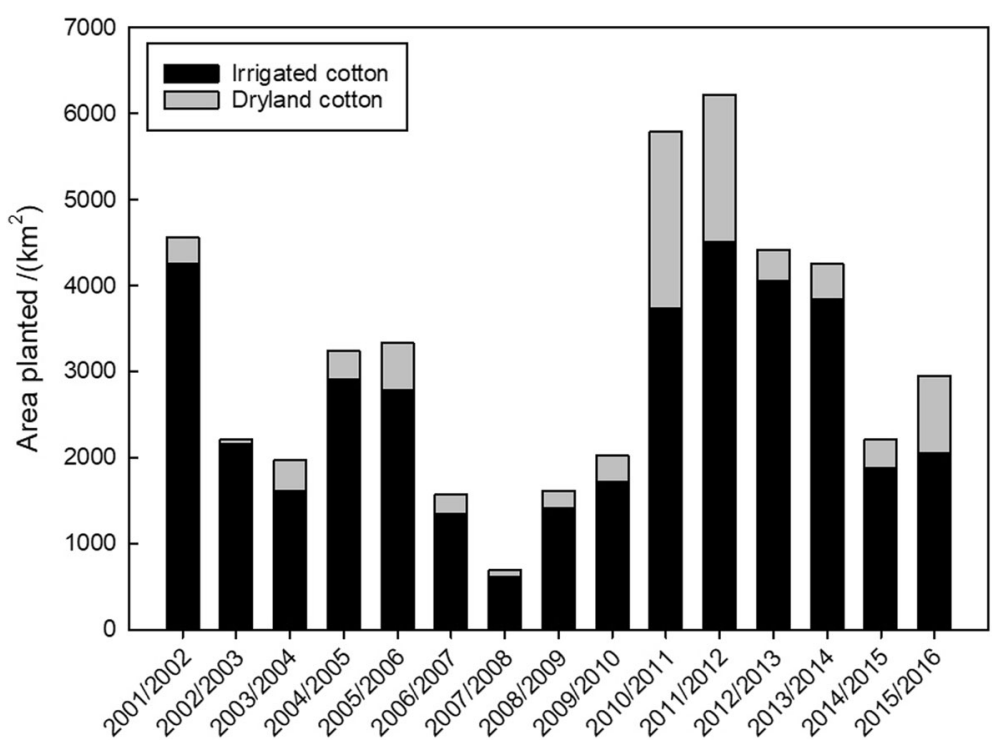

Fig. 1 Area planted for irrigated and dryland cotton in Australia (Anon 2017) 
mineralisation is an important source of $\mathrm{N}$ for the crop and yields may be lifted with an increased application of fertiliser.

Regional NFUE data were sourced from Roth Rural (2014) grower surveys. Measured regional data were sourced from the Action on the Ground field trials (Schwenke 2017), CottonInfo on-farm trials (Welsh et al. 2017), CottonInfo nutrition case study of the CottonInfo $\mathrm{N}$ rate trials, and the Cotton Seed Distributor (CSD) variety trials across the Australian irrigated cotton sector from 2008 to 2012 (Anon 2013).

\section{Results and discussion}

\section{National and regional scale nitrogen fertiliser use} efficiency

At the national scale, NFUE is outside the critical limits identified by Rochester (2014) for both dryland and irrigated cotton production (Fig. 2). It must be noted that Rochester's (2011b) NFUE critical limits were derived from irrigated trials, and that further work is needed to establish its efficacy in dryland systems. It is apparent from Rochester (2011a) that (a) constraints other than $\mathrm{N}$ deficiency are limiting yield, and (b) that the applied $\mathrm{N}$ fertiliser is not leading to increased lint yields, especially at rates $>290 \mathrm{~kg} \cdot \mathrm{hm}^{-2}$ of N. NFUE in dryland production is higher than that of the irrigated systems, with harvested lint matching optimal NFUE expected yields at fertiliser rates $<75 \mathrm{~kg} \cdot \mathrm{hm}^{-2}$ of $\mathrm{N}$ (Kruizinga and Wells 1992). Unfortunately, $\mathrm{N}$ application or product data do not exist for every year nationally or regionally within the Australia cotton sector.

Regional grower survey data from the 2012/13 season (Roth Rural 2014) revealed that, on average, industry-wide
NFUE was below the optimum range of 13-18 across all regions in irrigated systems. This indicates that in irrigated cotton systems, on average more $\mathrm{N}$ fertiliser was applied than was required, with the excess $\mathrm{N}$ most likely lost through denitrification (Grace et al. 2016; Macdonald et al. 2015). When assessed separately, dryland production NFUE was $>18$, confirming that it is possible to grow cotton within the expected NFUE ranges in each district (Fig. 3). Application rates in dryland production rarely exceed $100 \mathrm{~kg} \cdot \mathrm{hm}^{-2}$ of $\mathrm{N}$, with lint production expected to plateaux above $75 \mathrm{~kg} \cdot \mathrm{hm}^{-2}$ of $\mathrm{N}$ (Kruizinga and Wells 1992). A re-examination of Kruizinga and Wells (1992) dryland cotton NFUE is warranted due to the availability of new varieties and the potential management and long-term soil resilience implications of the continued removal of mineralised soil $\mathrm{N}$ suggested by these high NFUE values.

\section{Field trial data}

Long-term field trial data of Cotton Seed Distributers (CSD) showed that cotton can be grown within a NFUE range of $13-18$ at fertiliser rates between 100 and 300 $\mathrm{kg} \cdot \mathrm{hm}^{-2}$ of $\mathrm{N}$ (Fig. 4). In some instances, the conversion of applied $\mathrm{N}$ to lint was greater than expected (NFUE > 18), which indicates that non-stress conditions occurred during these seasons and that additional $\mathrm{N}$ may have been sourced from mineralised soil $\mathrm{N}$ or residual $\mathrm{N}$ from previous seasons.

$\mathrm{N}$ rate trials by CottonInfo (Anon 2013) showed no yield response to increased $\mathrm{N}$ application (Fig. 4), indicating that $\mathrm{N}$ was not the limiting factor in terms of production. Two more recent $\mathrm{N}$ studies (Schwenke 2017; Welsh et al. 2017) showed similar results (Fig. 5), demonstrating no increases

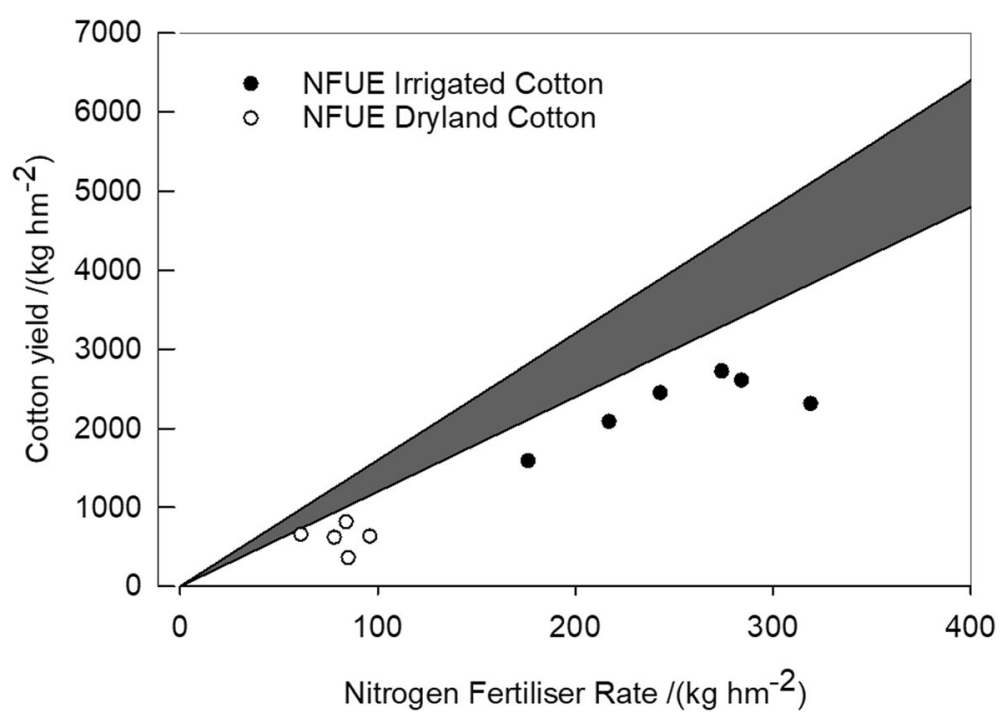

Fig. 2 NFUE in the Australian irrigated and dryland cotton industries. Data correspond to 2001/02, 2010/11 and 2012/13-2015/16 seasons. The shaded area represents Rochester's (2014) optimal NFUE range 


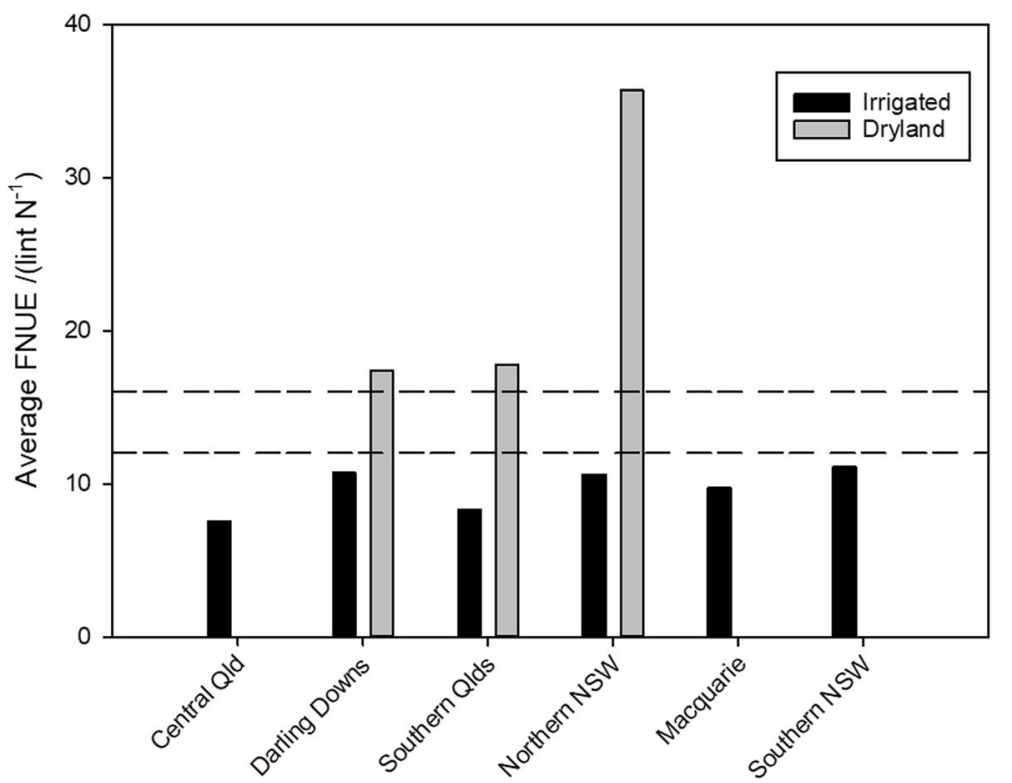

Fig. 3 Average NFUE for six Australian cotton growing regions during the 2012-2013 season. The dash lines represent the optimum NFUE determined by Rochester (2014). Data sourced from Roth Rural (2014)

in yield with increased fertiliser application across different regions. The Action on the Ground (farmers rate and $+/-25 \% \mathrm{~N}$ rate) (Schwenke 2017) and CottonInfo on-farm (Welsh et al. 2017) trials (Fig. 4-5) were both conducted on-farm, the results indicating that there was sufficient $\mathrm{N}$ in the soil profile to maximise production at fertiliser rates of $150 \cdot \mathrm{hm}^{-2}$ of $\mathrm{N}$. These lower fertilizer rates may lead to an overall decline in soil $\mathrm{N}$ content and potential crop deficiencies, particularly if there is insufficient residual $\mathrm{N}$ from the previous season or no legume rotation or addition of organic amendments.

Constable and Bange (2015) suggested that the theoretical maximum lint yield is $5 \mathrm{t} \cdot \mathrm{hm}^{-2}$ of lint, and that according to Rochester (2014) this would require the application of $320-420 \mathrm{~kg} \cdot \mathrm{hm}^{-2}$ of $\mathrm{N} . \mathrm{N}$ rates above $420 \mathrm{~kg} \cdot \mathrm{hm}^{-2}$ of $\mathrm{N}$ theoretically cannot produce any further lint and would be excessive if there are no losses. At rates of $300-440 \mathrm{~kg} \cdot \mathrm{hm}^{-2}$ of $\mathrm{N}$ it would be expected that approximately 3.6 to 5.0

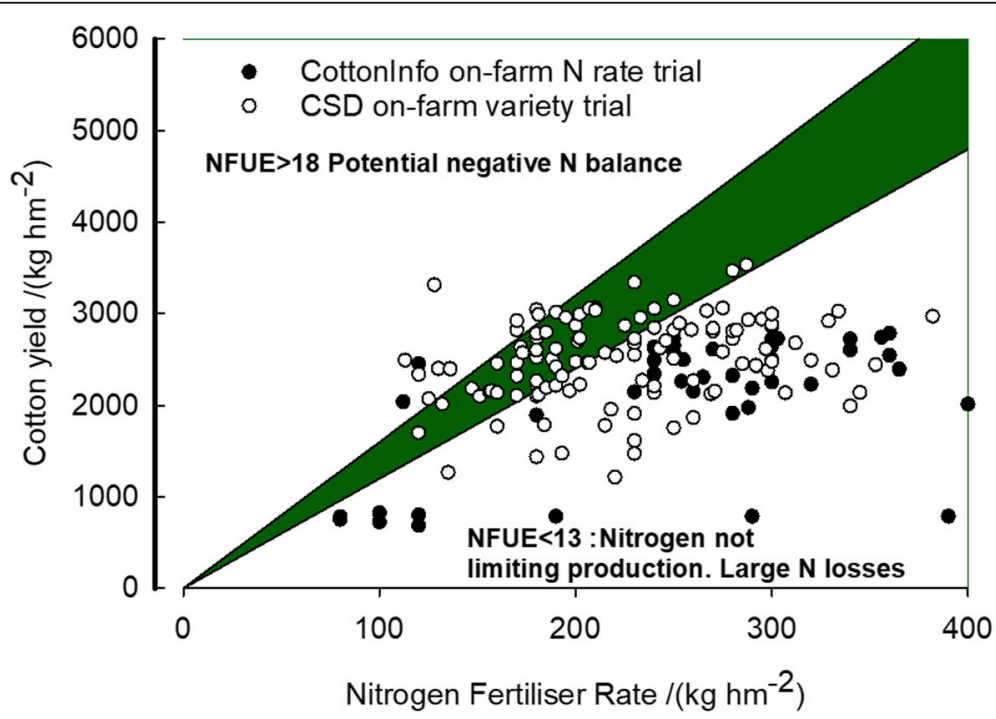

Fig. 4 NFUE of the 2008-2012 CottonInfo rate trials and the CSD farm variety trials (Anon 2013). Trial sites were located in all cotton production irrigation regions 


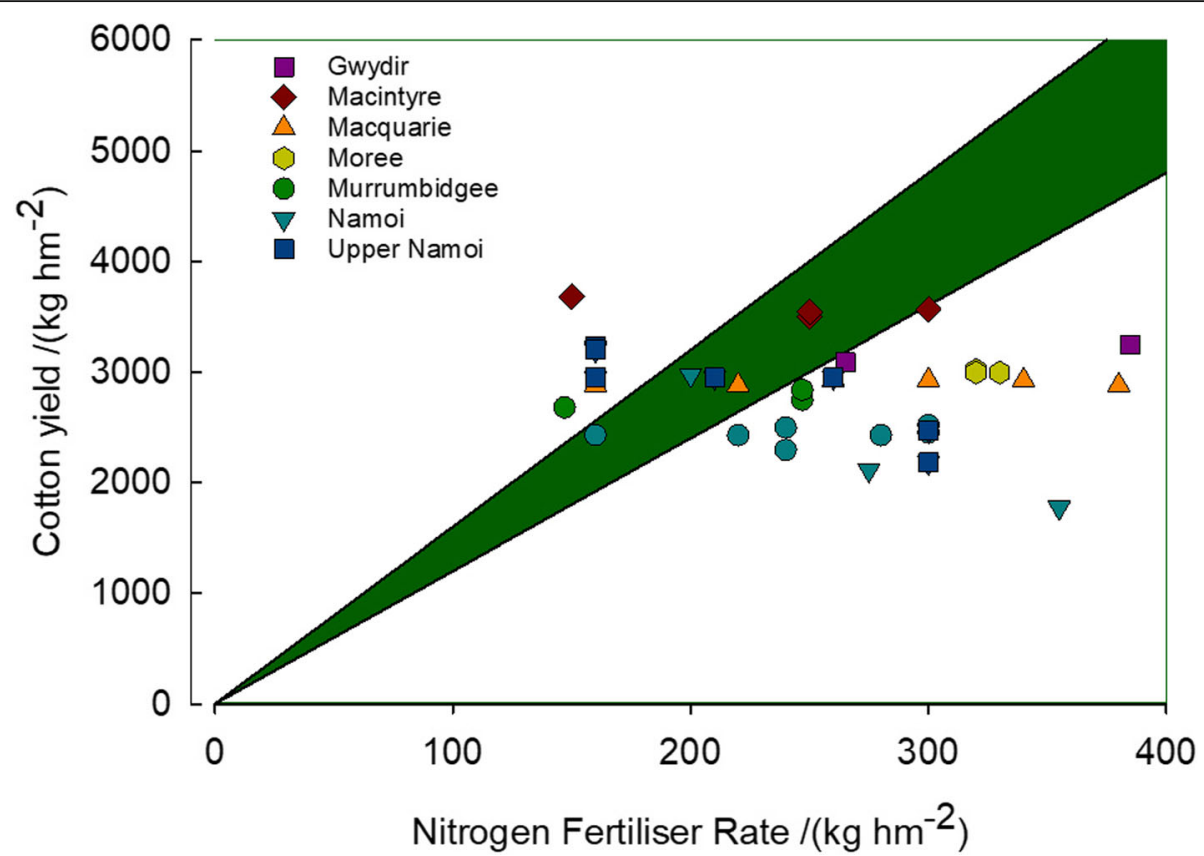

Fig. 5 NFUE in the Action on the Ground (Schwenke 2017) and Cottonlnfo trials (Anon 2013) in irrigated cotton systems

$\mathrm{t} \cdot \mathrm{hm}^{-2}$ of lint could be produced, and yet this is not observed in the field. Anecdotal evidence based on cotton picker yield monitoring, however, suggests that lint yields within cotton fields can range between $2.0-3.6 \mathrm{t} \cdot \mathrm{hm}^{-2}$ of lint. A significant improvement would be the calibration of yield monitoring across the industry.

It is clear from recent studies that across all growing regions, conversion of fertiliser $\mathrm{N}$ into increased lint production is not uniformly occurring at application rates greater than $200-240 \mathrm{~kg} \cdot \mathrm{hm}^{-2}$ of $\mathrm{N}$. This indicates that factors other than $\mathrm{N}$ availability are limiting yield, and that the lower observed NFUE values may be caused by subsoil constraints such as sodicity and compaction (Dodd et al. 2013). There is a need to investigate the impact of subsoil constraints on yield and NFUE. This kind of research will enable growers to manage the causes of their production deficits. Future researches should utilise on-the-go sensing and zonal management to identify, better understand, and target subsoil constraints that are limiting yield.

The NFUE data shown in Figs. 4 and 5 indicated that excess $\mathrm{N}$ is being applied to the fields in response to a lack of lint production. Unfortunately, the majority of this $\mathrm{N}$ is lost via denitrification to the atmosphere, with a portion also lost in surface run-off, transformed and lost as the powerful greenhouse gas nitrous oxide $\left(\mathrm{N}_{2} \mathrm{O}\right)$, or lost to deep drainage, potentially affecting groundwater systems (Macdonald et al. 2016b). These losses further emphasise the importance of improving NFUE across the industry.

\section{N Fertiliser decision support tools}

Australian cotton industry consultants and agronomists use a range of fertiliser decision support platforms that include, but are not limited to, Nutrient advantage advice, Back paddock soil mate and NutriLogic (Todd 2016). Other decision tools used widely in the cotton industry for fertiliser decision making include soil tests, nutrient budgeting, leaf petiole testing, N-TESTER \& imagery and seasonal climate forecasts (Todd 2016). Field history, previous experience and standard rates established over a period are also cited in the survey as influencing fertiliser decisions. A comprehensive review of various fertiliser decision support tools and reasons for their adoption or limitations is warranted. Existing fertiliser decision support tools need to be upgraded to assist growers and consultants in improving their NFUE. Decision tools should account for seasonal weather limitations and their impact on split fertiliser applications, and offer alternate solutions to fertiliser management where water-run fertiliser applications need to be skipped to avoid waterlogging.

\section{$\mathrm{N}$ fertiliser rate}

At national and regional scales, NFUE is below industry expectations. Over fertilising is a particular problem for irrigated cotton systems, and can lead to delayed maturity, defoliation difficulties, boll drop, increased rates of disease, rank cotton and leaf trash in lint (Marshall et al. 1996). It is clear from the $\mathrm{N}$ rate trials at Narrabri and from those conducted in other regions that increasing $\mathrm{N}$ 
rates above $250-300 \mathrm{~kg} \cdot \mathrm{hm}^{-2}$ of $\mathrm{N}$ does not result in extra lint (Marshall et al. 1996; Fig. 3, 4 and 5). This indicates that the availability of $\mathrm{N}$ is not the key production constraint in these trials, that $\mathrm{N}$ losses are occurring from the system, and that the industry needs to identify the yield constraining factors. At the same time, the adoption of existing fertiliser decision support systems that incorporate residual soil fertility, such as Nutrilogic, is limited. A recent crop consultant survey suggests that the use of Nutrilogic for fertiliser decision support is lower than other tools (Todd 2016). A reduction in the application of fertiliser $\mathrm{N}$ and the utilisation of myBMP, Nutrilogic and other industry funded guidelines should be adopted.

In contrast, the dryland sector may be mining soil $\mathrm{N}$ due to low fertiliser inputs that do not match $\mathrm{N}$ removal and $\mathrm{N}$ losses. Going forward, monitoring and evaluation of the soil resource base are required. Growers who are not practising myBMP, utilising cover crops, legumes and residue retention should be encouraged to modify their practices to maintain soil resilience.

\section{Timing of $\mathbf{N}$ fertiliser application}

Growers often apply fertiliser $\mathrm{N}$ as early pre-plant applications up to eight months prior to sowing. It has been shown that losses from these pre-plant applications can be significant, with only $20 \%$ of the applied fertiliser $\mathrm{N}$ being available to the cotton plant at sowing (Humphreys et al. 1990). This study occurred in 1988 and 1989 when April rainfall in both years was approximately $130 \mathrm{~mm}$ above average. These conditions would have promoted enhanced denitrification of the fertiliser $\mathrm{N}$ which contributed to large losses. In drier conditions, the overall losses would be lower. The potential for losses is minimised when the $\mathrm{N}$ fertiliser is applied closer to sowing (August-September) rather than earlier in the year (Constable and Rochester 1992; Humphreys et al. 1990). Significant losses due to denitrification can still occur when the fertiliser is applied nearer to sowing (Humphreys et al. 1990) due to waterlogging from excessive rainfall or irrigation. The only way to lower the risk of denitrification caused by rainfall is to delay the formation of nitrate- $\mathrm{N}$ from the applied fertiliser, either chemically through nitrification inhibitors, or physically, through slow-release coatings of polymers etc. If irrigation techniques are the cause of the denitrification, then methods that reduce waterlogging should be investigated.

Marshall et al. (1996) found that NFUE increased when $\mathrm{N}$ fertiliser was applied in the weeks prior to sowing and by flowering. This corresponds to findings of Humphreys et al. (1990) where most of the $\mathrm{N}$ uptake occurred during mid-November to January. Rather than late-season applications, it is more important to obtain a large plant, rich with $\mathrm{N}$, prior to boll production (Crowther 1934), which means full fertilisation should occur before boll production. It is at boll production that soil $\mathrm{N}$ up-take by the plant dramatically reduces, and translocation of $\mathrm{N}$ from the leaves to bolls occurs (Crowther 1934).

The risk of $\mathrm{N}$ run-off and leaching loss is greater early in the irrigation season when the crop is small (Macdonald et al. 2017; Macdonald et al. 2016c). Another timing option increasingly practiced by cotton growers is to split $\mathrm{N}$ applications between pre-plant and in-crop applications in conjunction with early season irrigation events. This in-crop N should have a better NFUE as N is applied directly as the plant needs it prior to boll production. This strategy should be monitored and evaluated in the field, and modelled under a range of conditions to test whether it is suitable for widespread adoption. The split $\mathrm{N}$ application includes a risk factor for growers when high rainfall events coincide with the application timing.

\section{Improving $\mathbf{N}$ translocation within cotton plants}

The latest cotton yield survey suggests that the average industry yield for irrigated cotton is $2.3 \mathrm{t} \cdot \mathrm{hm}^{-2}$, with the top $20 \%$ of growers reporting a lint yield of $3.1 \mathrm{thm}^{-2}$ (Cotton Australia, 2017). These reported yields were well below the maximum possible theoretical yield of $5 \mathrm{t} \cdot \mathrm{hm}^{-2}$, which would require a dry matter production of $20-30 \mathrm{t}_{\mathrm{hm}} \mathrm{h}^{-2}$ and $\mathrm{N}$ uptake of $384 \mathrm{~kg} \cdot \mathrm{hm}^{-2}$ of $\mathrm{N}$ to achieve (Constable and Bange 2015). To increase the higher $\mathrm{N}$ uptake and improve the harvest index, future researches need to focus on improving our understanding of $\mathrm{N}$ translocation within cotton plants. Nitrogen physiological use efficiency (NPUE) as described below (Eq. 2) should also be factored to enhance the NFUE.

$$
\text { NPUE }=\frac{\text { Lint produced }\left(\mathrm{kg} \cdot \mathrm{hm}^{-2}\right)}{\text { Plant } N \text { uptake }\left(\mathrm{kg} \cdot \mathrm{hm}^{-2}\right)}
$$

\section{Irrigation technique}

Variations in irrigation technique are not commonly directly linked with NFUE in the literature, with environmental studies assessing $\mathrm{N}$ losses often the best proxies for estimating NFUE. McHugh et al. (2008) compared $\mathrm{N}$ runoff losses between furrow and subsurface drip irrigation systems in Queensland cotton, showing losses of $15.1 \mathrm{~kg} \cdot \mathrm{hm}^{-2}$ of $\mathrm{N}$ and $2.9 \mathrm{~kg} \cdot \mathrm{hm}^{-2}$ of $\mathrm{N}$, respectively, under comparable water usage conditions. This difference in NFUE was further pronounced under reduced water usage, where subsurface drip $\mathrm{N}$ losses decreased to negligible levels. Bronson et al. (2017) found significant differences in NFUE between surface (flood) and overhead sprinkler irrigation systems in Central Arizona, reporting $\mathrm{N}$ recovery efficiencies of $21 \%-61 \%$ for surface irrigation, and $81 \%-97 \%$ for overhead sprinkler irrigation at low $\mathrm{N}$ rates $\left(60-76 \mathrm{~kg} \cdot \mathrm{hm}^{-2}\right.$ of N). Furthermore, Bronson et al. 
(2017) estimated deep drainage in the surface irrigation system at $4 \%-11 \%$ of applied irrigation water and rain, with deep drainage $\mathrm{NO}_{3}{ }^{-} \mathrm{N}$ losses constituting the most significant $\mathrm{N}$ loss pathway. No appreciable deep drainage and associated $\mathrm{N}$ loss were reported for the overhead sprinkler irrigation systems, due to a reduction in waterlogging (Bronson et al. 2017). In a qualitative review of $\mathrm{N}$ and irrigation techniques, Barakat et al. (2016) postulated that flood and overhead irrigation techniques led to greater denitrification and $\mathrm{N}$ loss than subsurface and surface drip irrigation. The mounting evidence indicates that furrow irrigation, which is the most common irrigation technique used in Australian irrigated cotton, results in the lowest NFUE of all common irrigation techniques.

Research directly comparing the NFUE of different irrigation methods should be undertaken, building on the work of Bronson et al. (2017), Barakat et al. (2016) and McHugh et al. (2008). Many Australian studies include data that could theoretically be collated in a meta-analysis to suggest relative NFUE values as a function of irrigation technique (furrow irrigation: (Antille et al. 2016a, 2016b; Grace et al. 2016); overhead irrigation:(Scheer et al. 2016); drip irrigation: (McHugh et al. 2008)); however, with the extensive list of uncontrolled variables and few studies using non-furrow irrigation, this would be a poor substitute for a single field-based study directly comparing their efficacies.

The NFUE implications of water-running fertilisers as an alternative to solid (banded or broadcast) or gaseous $\mathrm{N}$ delivery methods is also poorly understood in the literature. Forty-six percent of Australian irrigated cotton growers used water-run $\mathrm{N}$ in the 2015/2016 summer season, with seasonal rates varying from 14 to $220 \mathrm{~kg} \cdot \mathrm{hm}^{-}$ ${ }^{2}$ of N (Sparks 2017). However, beyond the improvements to NFUE derived from splitting the $\mathrm{N}$ applications across several events, the NFUE implications of applying $\mathrm{N}$ aqueously over other methods are not well characterised. Water-running $\mathrm{N}$ also has application uniformity problems, with many growers unsure of its efficacy and hesitant to adopt fertigation practices due to restricted $\mathrm{N}$ visibility. Theoretically, water-running $\mathrm{N}$ should result in a uniform fertiliser application, and indeed Antille and McCarthy (2014) comment on the uniformity of $\mathrm{N}$ application in their water-run study; however, minimal data exist confirming the uniformity and efficacy of water-run $\mathrm{N}$ applications, and this should be a focus of future research. Bronson et al. (2017) found no differences in yield between direct drilling of $\mathrm{N}$ and fertigation in surface irrigated cotton, but made note of the lack of comparable studies.

Recirculation of tail-water is the practice of Australian cotton industry, with moderate concentrations of residual $\mathrm{N}$ in supply channels leached from the hills in the fields
(Macdonald et al. 2016b). As such, $\mathrm{N}$ losses can occur from the irrigation network external to the field regardless of whether intentional fertigation is occurring. Macdonald et al. (2016a) estimated $\mathrm{N}_{2} \mathrm{O}-\mathrm{N}$ gaseous emissions from non-fertigation cotton irrigation networks at $<0.02 \%$ of applied $\mathrm{N}$ fertiliser to the land surface, with greater $\mathrm{N}$ losses as $\mathrm{N}_{2}$ emissions also expected to occur, but not easily measurable. These fugitive emissions may increase significantly in scenarios of fertigation or $\mathrm{N}$ over-application, potentially even exponentially in line with field emission estimates by Grace et al. (2016).

\section{Soils}

Historically, most of the cotton grown in Australia has been on cracking clay soils (Constable and Rochester 1992; Hulugalle and Scott 2008), and as such the bulk of Australian cotton nitrogen researches have taken place on these soils (Grace et al. 2016; Macdonald et al. 2016c; Scheer et al. 2016). Key findings like Rochester's (2014) optimal NFUE window have been determined on these cracking clay soils. As economic and climatic drivers extend the cotton belt further from its historical centres, cotton is increasingly being grown on different soil types. Deviation in soil attributes (fertility, particle size, elemental composition, $\mathrm{pH}$, colour, etc.) from the traditional soils could mean that new cotton-growing regions don't fit the same optimum NFUE values determined for cracking clays. Research characterising the effects of specific soil attributes on NFUE would provide the industry with valuable tools for predicting which areas are suitable for cotton expansion.

Soil processes are also key constraints to production. Bronson et al. (2017) emphasised that soil $\mathrm{N}$ mineralisation rates were poorly understood and consistently underestimated in irrigated cotton, resulting in significant over application of $\mathrm{N}$ fertilisers. It is recommended that improved $\mathrm{N}$ mineralisation characterisation be undertaken using a combination of direct sampling measurements, aerial and remote sensing techniques, and modelling.

\section{Improving soil management}

Over the last 30 years NFUE in the Australian cotton industry has been assessed using ${ }^{15} \mathrm{~N}$ and apparent $\mathrm{N}$ uptake studies, revealing that only $40 \%-60 \%$ of the $\mathrm{N}$ applied prior to sowing is taken up by the plant (Constable and Rochester 1988; Humphreys et al. 1990; Macdonald et al. 2016c; Rochester 2011a, 2012). A common misconception is that the bulk of the fertiliser $\mathrm{N}$ not taken up by the plant is immobilised in the soil and will be released in subsequent years. This is not the case, with most studies showing that only $10 \%-30 \%$ of the applied $\mathrm{N}$ remains in the soil after the cropping season, stored in macro and micro biota or in the soil's organic or inorganic pools (Constable and Rochester 1988; Humphreys et al. 1990; 
Macdonald et al. 6c; Rochester 2011a, 2012). Overall, the soil supplies $30 \%-50 \%$ of the $\mathrm{N}$ required by cotton plants during a season (Macdonald et al. 2016c; Rochester 1994), with fertile soils resulting in improved NFUE (Humphreys et al. 1990). This means that management of the soil $\mathrm{N}$ budget is critical to achieving higher NFUE (Rochester and Bange 2016).

A key aspect of soil management for improved NFUE is to utilise crop rotations with legumes, and to plant cover crops during fallow periods. Soil organic carbon levels are generally declining with cotton monoculture and cotton-wheat rotations due to an insufficient amount of residue returned to the soil (Hulugalle and Scott 2008). However, recent researches on cotton cropping systems that incorporate legumes and cover crops have shown their ability to build up soil organic carbon (Rochester 2011b), and further contribute to crop nutrition by enhancing soil organic N. Overall, growing legumes in traditional fallows improve soil organic matter levels, fertility, and soil $\mathrm{N}$ (Marshall et al. 1996), with legume soil $\mathrm{N}$ inputs of $120 \mathrm{~kg} \mathrm{~N} \cdot \mathrm{hm}^{-2}$ possible (Rochester and Peoples 1998). Together, the use of legume winter crops and a non-irrigated covered fallow can regularly produce a 3 $\mathrm{t} \cdot \mathrm{hm}^{-2}$ lint yield using $200-220 \mathrm{~kg} \mathrm{~N} \cdot \mathrm{hm}^{-2}$ (Rochester 2011a, Rochester and Constable 2015). Including non-legume crops in rotations will also improve soil health and cotton yields, with cotton after wheat showing $30 \%$ yield improvements (Rochester and Peoples 1998). Compared with continuous cotton, the profitability of cotton-wheat rotations is also more resilient to fluctuations in the price of cotton lint, fuel and nitrogen fertiliser (Hulugalle and Scott 2008). To further improve soil health, it is recommended that crop stubbles be incorporated and residue burning avoided (Rochester and Peoples 1998). While there are on-farm logistical impediments to the adoptation of cover-cropping and legume rotations, and the opportunity cost of soil water use by the cover crop needs to be considered, the yield and long term soil health benefits of rotational cropping can be significant.

Soil compaction is another key management practice that contributes to reduced NFUE. Soil compaction caused through natural (flooding) or management processes (traffic, wet tillage, excessively heavy pickers) can reduce NFUE by promoting denitrification (Constable and Rochester 1992; Rochester 1994) and limiting plant growth through root inhibition (Antille et al. 2016a, 2016b). Soil compaction can reduce cotton yields by 35\% (Daniells 1989), and thus may be a key reason for low NFUE values. Soil compaction is not permanent and can be mitigated (Bennett et al. 2015) over time through controlled traffic regimes, rotational cropping, reduced tillage, and by reducing water pooling and flooding. The Australian cotton industry has recently adopted the roundbale module cotton picker, which can weigh in excess of
$32 \mathrm{t}$ when fully loaded. While this picker is perceived to be labour and time efficient compared with previous cotton pickers, its impact on soil compaction and any indirect effect on NFUE needs to be evaluated.

\section{Climate change}

Changing climate is likely to have a significant effect on cotton yields in Australia and around the world (Broughton et al. 2017; Haim et al. 2008; Reddy et al. 2002; Sankaranarayanan et al. 2010). For the majority of Australia's cotton growing regions, climate change will bring increased severity and frequency of heatwaves, an increase in drought intensity, and a reduction in rainfall, in addition to a global increase in atmospheric $\mathrm{CO}_{2}$ concentration.

Increased ambient temperatures are largely predicted to have a negative effect on cotton production. In controlled experiments, early-season biomass was shown to increase under elevated temperature conditions; however, midand late-season growth was restricted, with boll-retention increasingly adversely affected with elevated temperatures (Broughton et al. 2017; Reddy et al. 1997). Furthermore, as ambient temperatures increase, so too do crop water requirements (Broughton et al. 2017). This will likely result in increased irrigation requirements, which will be further exacerbated by the reduced rainfall predicted for much eastern Australia.

Conversely, increases in $\mathrm{CO}_{2}$ are largely seen as positive for cotton production, with increases in vegetative biomass and photosynthesis rates observed in experiments (Broughton et al. 2017; Haim et al. 2008; Reddy et al. 2002; Sankaranarayanan et al. 2010). In treatments with elevated $\mathrm{CO}_{2}$ combined with higher temperatures, however, crop yields were affected detrimentally, with reduced productivity from high temperatures outweighing improvements from the elevated $\mathrm{CO}_{2}$. Increases to water use efficiency were also noted under elevated $\mathrm{CO}_{2}$ conditions (Broughton et al. 2017).

The cotton plant's response to elevated temperature and $\mathrm{CO}_{2}$ is not uniform, with significant variation between different species and cultivars. It is recommended that cultivar selection research continue to be pursued with a focus on traits encouraging heat-cold-tolerance, water use efficiency, and performance under elevated $\mathrm{CO}_{2}$ conditions. Despite the potential impact of climate change there are no studies that assess both soil $\mathrm{N}$ function and NFUE in cotton cropping systems under future climatic conditions.

\section{Conclusions and future NFUE research recommendations}

There have been significant researches on fertiliser $\mathrm{N}$ in the cotton industry over the last 40 years. Despite this investment, NFUE is currently below optimum and there is significant potential for its improvement in the cotton 
industry. It is apparent that improvements can be made in the time of $\mathrm{N}$ fertiliser application strategies, but these cannot improve NFUE until $\mathrm{N}$ fertiliser rates are reduced from luxury to optimum levels. Further improved management of the soil $\mathrm{N}$ could help improve yields and lower fertiliser use. A key objective of this review was to identify research gaps and suggests future research directions. Suggested future research directions include:

- Identification of the impacts of different soil attributes on yield and NFUE to help growers identify and manage the causes of reduced yield, and to facilitate industry prediction of suitable regions for cotton expansion.

- Analysis of the barriers to adoption of the legume-cover-fallow cotton rotation; a baseline NFUE assessment of farms that practice such rotations; a modelling assessment of the impacts of different crop rotations and management practices on soil carbon and nitrogen; an analysis of the barriers to adoption of optimum $\mathrm{N}$ fertiliser rates.

- Assessment of the uniformity of fertiliser distribution in water-run $\mathrm{N}$ treatments, specifically differentiating between 'syphon' and 'bankless channel' flood irrigation arrangements, which are the two most common water-run setups.

- Further assessment of the relative NFUEs of different irrigation methods, particularly in the context of reducing waterlogging by getting water on, in and off in the minimum time possible.

- Assessment of the $\mathrm{N}$ losses from irrigation networks external to the field in water-run $\mathrm{N}$ treatments as fugitive emissions, deep drainage and surface runoff.

- Examination of integrated automated precision irrigation and fertiliser systems.

- A comprehensive review of $\mathrm{N}$ fertiliser decision support tools and the reason for the adoption or limitation of the existing tools.

- Increasing the soil organic nitrogen pool and quantifying $\mathrm{N}$ mineralisation rates for all cotton soils.

- Overcoming the logistical challenge of applying $\mathrm{N}$ in a timely and / or more precise manner to an irrigated cotton crop, so that supply better matches demand.

\section{Abbreviations}

CSD: Cotton Seed Distributors; N: Nitrogen; NFUE: Nitrogen fertiliser use efficiency; NPUE: Nitrogen physiological use efficiency; NSW: New South Wales

\section{Acknowledgements}

The authors gratefully acknowledge the three reviewers who provided critical feedback on the manuscript.

\section{Funding}

This work was funded by the Australian Government, Department of Agriculture and Water Resources, and the Cotton Research and Development Corporation's Rural Research and Development for Profit Project "More profit from nitrogen: enhancing the nutrient use efficiency of intensive cropping and pasture systems". Latimer JO was also funded by the Cotton Research and Development Corporation's PhD scholarship.

Availability of data and materials

All data used in this paper were from previously published research papers and reports.

\section{Authors' contributions}

Macdonald BCT, Latimer JO, Schwenke GD, Nachimuthu G and Baird J designed the paper's approach and contributed to the writing. Macdonald $\mathrm{BCT}$ led the writing and data analysis. All authors read, edited and approved the final manuscript

Ethics approval and consent to participate Not applicable.

Consent for publication

Not applicable.

\section{Competing interests}

The authors declare that they have no competing interests.

\section{Author details}

${ }^{1}$ CSIRO Agriculture and Food, Black Mountain, Canberra, ACT, Australia. ${ }^{2}$ The Fenner School of Environment and Society, the Australian National University, Canberra, ACT, Australia. ${ }^{3} \mathrm{NSW}$ Department of Primary Industries, Tamworth Agricultural Institute, Tamworth, NSW, Australia. ${ }^{4}$ NSW Department of Primary Industries, Australian Cotton Research Institute, Narrabri, NSW, Australia.

Received: 5 August 2018 Accepted: 9 November 2018

Published online: 18 December 2018

\section{References}

Anon. Nutrition case study: The nitrogen challenge: Trial results show cost savings. 2013. https://www.cottoninfo.com.au/sites/default/files/documents/ Nutrition\%20case\%20study.pdf.CottonInfo. Accessed 28 Sept 2018.

Anon. The Australian cotton year book. The Australia Cotton Grower. Toowoomba: Greenmount Press. 2017.

Antille DL, Bennett JM, Jensen TA. Soil compaction and controlled traffic considerations in Australian cotton-farming systems. Crop and Pasture Science. 2016a;67:1-28.

Antille DL, Huth NI, Eberhard J, et al. The effects of coal seam gas infrastructure development on arable land in southern Queensland, Australia: field investigations and modeling. Transactions of the ASABE. 2016b; 59(4): 879-901.

Antille DL, McCarthy A. Field scale evaluation of furrow fertigation using liquid nitrogen. our fibre, our focus, our future. In: Cotton Research and Development Corporation, 17th Australian Cotton Conference. 5-7 August 2016, Gold Coast, Australia.

Barakat M, Cheviron B, Angulo-Jaramillo R. Influence of the irrigation technique and strategies on the nitrogen cycle and budget: a review. Agric Water Manag. 2016;178:225-38.

Bennett JM, Woodhouse NP, Keller T, et al. Advances in cotton harverting technology: a review and implications for the john deere round baler cotton picker. The Journal of Cotton Science. 2015;19:225-49.

Boyce Chartered Accountants. The 2017 Australian cotton comparative analysis. 2017. https://www.boyceca.com/boyce-newsfeed/category/australiancotton-comparative-analysis. Accessed 28 Sept 2018.

Bronson KF, Hunsaker DJ, Mon J, et al. Improving nitrogen fertilizer use efficiency in surface- and overhead sprinkler-irrigated cotton in the desert southwest. Soil Sci Soc Am J. 2017:81:1401-12.

Broughton KJ, Bange MP, Duursma RA, et al. The effect of elevated atmospheric $\left[\mathrm{CO}_{2}\right]$ and increased temperatures on an older and modern cotton cultivar. Funct Plant Biol. 2017:44:1207-18.

Constable GA, Bange MP. The yield potential of cotton (Gossypium hirsutum L.) Field Crop Res. 2015;182:98-106. 
Constable GA, Rochester IJ. Nitrogen application to cotton on a clay soil: timing and soil testing. Agron J. 1988;80:498-502.

Constable GA, Rochester IJ. Can we be more accurate with N rates? In: Australian Cotton Growers' Research Association. Fifth Australian Cotton Conference: Genes to jeans. 12-14 August 1992, Broadbeach, Queensland, Australia.

Cotton Australia. Cotton library statistics. 2017. https://cottonaustralia.com.au/ cotton-library/statistics. Accessed 19 Oct 2017.

Crowther F. Studies in growth analysis of the cotton plant under irrigation in the Sudan. I. the effects of different combinations of nitrogen applications and water-supply. Ann Bot. 1934;48:877-913.

Daniells IG. Degradation and restoration of soil structure in a cracking clay used for cotton production. Aust J Soil Res. 1989;27:455-69.

Dodd K, Guppy CN, Lockwood PV, Rochester IJ. The effect of sodicity on cotton: does soil chemistry or soil physical condition have the greater role? Crop and Pasture Science. 2013;64(8):806-15.

Grace P, Shcherbak I, Macdonald B, et al. Emission factors for estimating fertiliserinduced nitrous oxide emissions from clay soils in Australia's irrigated cotton industry. Soil Research. 2016;54:598.

Haim D, Shechter M, Berliner P. Assessing the impact of climate change on representative field crops of israeli agriculture: a case study of wheat and cotton. Climate Change. 2008:86:425-40.

Hulugalle NR, Scott F. A review of the changes in soil quality and profitability accomplished by sowing rotation crops after cotton in Australian vertosols from 1970 to 2006. Aust J Soil Res. 2008;46:173-90.

Humphreys E, Freney JR, Constable GA, et al. The fate of your N fertiliser. In: Australian Cotton Growers' Research Association. Fourth Australian Cotton Conference: the Australian Cotton Industry under the Microscope. 8-9 August 1990, Broadbeach. p. 161-70.

Kruizinga J, Wells T. Varietal response to irrigation and nitrogen. In: Australian Cotton Growers' Research Association. Fifth Australian Cotton Conference: Genes to jeans. 12-14 August 1992, Broadbeach. p. 492.

Macdonald B, Ringrose-Voase A, Nadelko A, et al. Dissolved organic nitrogen contributes significantly to leaching from furrow-irrigated cotton-wheatmaize rotations. Soil Research. 2017;55:70-7. https://doi.org/10.1071/SR16047.

Macdonald BCT, Chang YF, Warneke S. Potential contributions of surface and ground water to nitrous oxide emissions from irrigated cotton production systems. Agric Water Manag. 2016a;168:78-84. https://doi.org/10.1016/j. agwat.2016.01.018.

Macdonald BCT, Nadelko A, Chang Y, et al. Contribution of the cotton irrigation network to farm nitrous oxide emissions. Soil Research. 2016b;54:651-8. https://doi.org/10.1071/SR15273.

Macdonald BCT, Chang YF, Nadelko A, et al. Tracking fertiliser and soil nitrogen in irrigated cotton: uptake, losses and the soil N stock. Soil Research. 2016c;55: 264-72. https://doi.org/10.1071/SR16167.

Macdonald BCT, Rochester IJ, Nadelko A. High yielding cotton produced without excessive nitrous oxide emissions. Agron J. 2015;107:1673-81.

Marshall J, Thomson S, Rochester I, et al. The benefits of rotation cropping to cotton. In: Australian Cotton Growers Research Assoication Inc. Eighth Australian Cotton Conference: Cotton on to the future. 14-16 August 1996, Gold Coast. p. 463-7.

McHugh AD, Bhattarai S, Lotz G, Midmore DJ. Effects of subsurface drip irrigation rates and furrow irrigation for cotton grown on a vertisol on off-site movement of sediments, nutrients and pesticides. Agron Sustain Dev. 2008; 28:507-19.

Pettigrew WT, Dowd MK. Nitrogen fertility and irrigation effects on cottonseed composition. Journal of Cotton Science. 2014;18:410-9.

Reddy KR, Doma PR, Mearns LO, et al. Simulating the impacts of climate change on cotton production in the Mississippi delta. Clim Res. 2002;2:271-81.

Reddy KR, Hodges HF, McKinion JM. A comparison of scenarios for the effect of global climate change on cotton growth and yield. Aust J Plant Physiol. 1997;24:707-17.

Rochester IJ. Growing high-yielding nitrogen-efficient cotton. In: Cotton Research and Development Corporation. 17th Australian Cotton Conference. 5-7 August 2014, Gold Coast, Australia.

Rochester IJ. Efficient nitrogen management in cotton In: Australian Cotton Growers Research Assoication Inc. 7th Australian Cotton Conference: The fabric of success. 10-12 August 1994, Gold Coast. p. 323-326.

Rochester IJ. Nutripak-A practical guide to cotton nutrition. Australian Cotton Cooperative Research Centre. 2001.

Rochester IJ. Assessing internal crop nitrogen use efficiency in high-yielding irrigated cotton. Nutr Cycl Agroecosyst. 2011a;90:147-56.
Rochester IJ. Sequestering carbon in minimum-tilled clay soils used for irrigated cotton and grain production. Soil Tillage Res. $2011 \mathrm{~b} ; 112: 1-7$.

Rochester IJ. Using seed nitrogen concentration to esitmate crop N use-efficiency in high-yielding irrigated cotton. Field Crop Res. 2012;127:140-5.

Rochester IJ, Bange M. Nitrogen fertiliser requirements of high-yielding irrigated transgenic cotton. Crop \& Pasture Science. 2016;67:641-8.

Rochester IJ, Constable GA. Improvements in nutrient uptake and nutrient use-efficiency in cotton cultivars released between 1973 and 2006. Field Crop Res. 2015;173:14-21.

Rochester IJ, Peoples MB. Optimising cotton nutrition. In: Australian Cotton Growers Research Assoication Inc. 9th Australian Cotton Conference: Cotton covering our future. 12-14 August 1998, Broadbeach. p. 139-144.

Roth G. Economic, environmental and soical sustainability indicators of the australian cotton industry. Narrabri; 2010. https://www.crdc.com.au/sites/default/files/pdf/ Economic\%2C\%20social\%20and\%20environmental\%20indicators\%20report.pdf. Accessed 28 Sept 2018.

Roth Rural. Cotton growing practices 2014: findings of CRDC's survey of cotton growers. Narrabri, NSW, Australia: Cotton Research and Development Corporation. 2014. http://hdl.handle.net/1/4089. Accessed 28 Sept 2018.

Sankaranarayanan K, Praharaj CS, Nalayini P, et al. Climate change and its impact on cotton (Gossypium sp.). Indian Journal of Agricultural Sciences. 2010; 80:561-75

Scheer C, Rowlings DW, Grace PR. Non-linear response of soil $\mathrm{N}_{2} \mathrm{O}$ emissions to nitrogen fertiliser in a cotton-fallow rotation in sub-tropical Australia. Soil Research. 2016;54:494-9.

Schwenke GD. Final report - CRDC - determining optimum nitrogen strategies for abatement of emission from different irrigated cotton systems. Canberra; 2017. https://www.crdc.com.au/. Accessed 28 Sept 2018.

Sparks M. Grower survey 2017. 2017. http://www.insidecotton.com/xmlui/handle/1/4541. Accessed 28 Sept 2018.

Todd L. Qualitative report on the 2015-2016 cotton season: a survey of consultants. Narrabri: CRDC. 2016.

Vitousek PM, Naylor R, Crews T, et al. Nutrient imbalances in agricultural development. Science. 2009;324:1519-20.

Welsh J, Smith J, Dickinson S, et al. Cottoninfo on-farm nitrogen trials and nitrogen use practices. Toowoomba; 2017. https://www.cottoninfo.com.au/ publications/cottoninfo-nitrogen-trials-report. Accessed 28 Sep 2018.

\section{Ready to submit your research? Choose BMC and benefit from:}

- fast, convenient online submission

- thorough peer review by experienced researchers in your field

- rapid publication on acceptance

- support for research data, including large and complex data types

- gold Open Access which fosters wider collaboration and increased citations

- maximum visibility for your research: over $100 \mathrm{M}$ website views per year

At $\mathrm{BMC}$, research is always in progress.

Learn more biomedcentral.com/submissions 